\title{
EDITORIAL
}

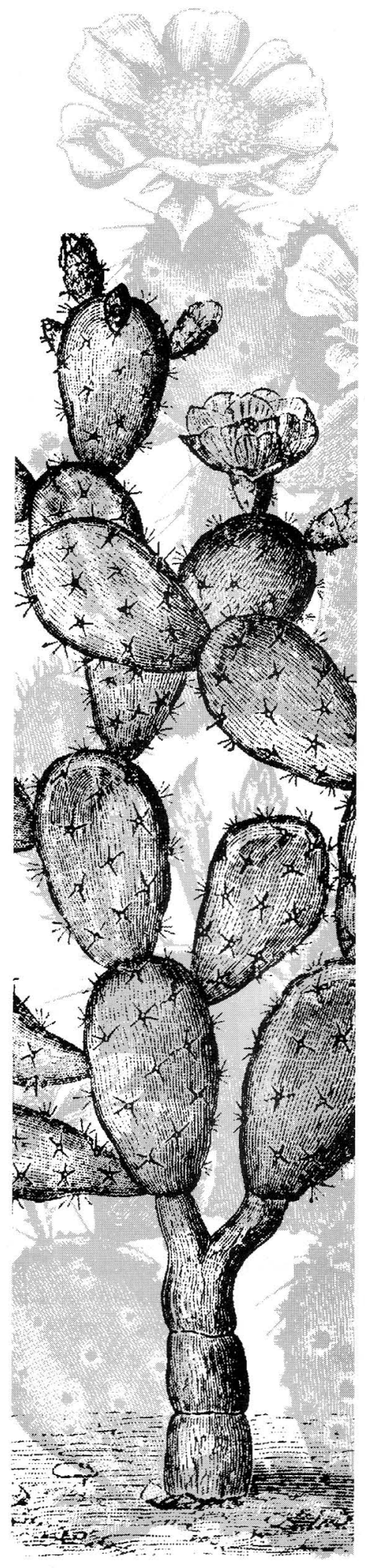

C on este ejemplar de 1999 se cierra un ciclo más de trabajo editorial. Como editor responsable de los últimos números me siento orgulloso de haber sido parte de un proyecto tan importante para el impulso de la botánica. Como miembro de la Sociedad Botánica me siento honrado de pertenecer a ella por su indeclinable empeño por avanzar y mejorar como asociación y parte de la comunidad científica. Sin embargo no dejo de preocuparme por la tendencia sostenida, desde hace varios años, de menospreciar y devaluar a las publicaciones científicas mexicanas al utilizar criterios externos a la actividad botánica misma como son los factores de impacto y los índices de citación. Estos criterios, aplicados en nuestro país, contrastan con la necesidad de impulsar las publicaciones científicas mexicanas, pues no contemplan las trayectorias históricas y editoriales, ni tampoco los objetivos de cada una de ellas. En particular la promoción de la botánica en México requiere de la publicación recurrente de trabajos florísticos y taxonómicos, fisiológicos y de anatomía, de ultraestructura y genética, por mencionar sólo algunos, y muchos de esos trabajos no son referidos en períodos inmediatos como para ser considerados en los factores de impacto y los índices de citación. Aunque estar incluido en los índices internacionales tiene cierta importancia, el objetivo de nuestra revista no debe ser limitado por los criterios para su permanencia en ellos.

Este número puede ser un buen ejemplo de lo anterior. Todos los artículos presentados son necesarios y útiles para el conocimiento de las plantas de nuestro país y regiones afines. La mayoría de ellos aportan elementos para entender la flora de la región y su conservación. Todos los artículos, de magnífica factura, pueden ser excluidos de las áreas científicas de moda o cuyo impulso actual es ascendente, sin embargo son algunos de los que mejor reflejan el mayor compromiso con las necesidades del conocimiento botánico de nuestro país y de toda Latinoamerica. Tres trabajos de ecología, uno de ficología, uno de fitogeogeografía, una nota botánica metodológica, y sobre todo los reunidos en la sección Perspectivas, editados por el Dr. Víctor Barradas, cierran ese círculo editorial.

Finalmente, le deseo al Dr. Rafael Lira, nuevo editor del Boletín, lo mejor para su trabajo en los próximos números. Estoy seguro que el Boletín seguirá avanzando, de manera muy firme, impulsando y manteniendo lo mejor de la botánica en México y todo ello a pesar de índices y factores de impacto.

\section{Eberto Novelo}

Editor 